Article

\title{
Assessment of the Hydro-Ecological Impacts of the Three Gorges Dam on China's Largest Freshwater Lake
}

\author{
Guiping Wu and Yuanbo Liu * \\ Key Laboratory of Watershed Geographic Sciences, Nanjing Institute of Geography and Limnology, \\ Chinese Academy of Sciences, Nanjing 21008, China; gpwu@niglas.ac.cn \\ * Correspondence: ybliu@niglas.ac.cn; Tel.: +86-25-8688-2164; Fax: +86-25-5771-4759
}

Received: 26 July 2017; Accepted: 18 October 2017; Published: 20 October 2017

\begin{abstract}
The Three Gorges Dam (TGD) has received increasing attention with respect to its potential effects on downstream hydro-ecosystems. Poyang Lake is the largest freshwater lake downstream of the TGD, and it is not immune to these impacts. Here, we combine hydrological observations, remote sensing, a geographic information system (GIS), and landscape ecology technology to investigate the variability and spatial pattern of the hydro-ecological alterations to Poyang Lake induced by the operation of the TGD. It was found that the TGD caused significant hydro-ecological alterations across the Poyang Lake wetland. Specifically, the TGD operation altered the seasonal inundation pattern of Poyang Lake and significantly reduced the monthly inundation frequencies (IFs), which were especially notable $(\sim 30-40 \%)$ from September to November. Spatially, the declining IFs led to an increase in the mudflat area that is suitable for the growth of vegetation. The vegetation area increased by $58.82 \mathrm{~km}^{2}$ and $463.73 \mathrm{~km}^{2}$ in the low- and high-water season, respectively, with the most significant changes occurring in the estuary delta of the Ganjiang and Raohe rivers. The results also indicated that the changes in the inundation pattern and floodplain vegetation have profoundly altered the structure and composition of the wetland, which has resulted in increased landscape diversity and a gradual increase in the complexity of the ecosystem composition under the influence of regulation of the TGD. Such results are of great importance for policymakers, as they may provide a reference for wetland water resource planning and landscape restoration in an operational dam environment.
\end{abstract}

Keywords: Poyang Lake; TGD; hydro-ecological impact; remote sensing; geographic information system

\section{Introduction}

Floodplain wetlands are the most productive and valuable ecosystems on earth [1]. They play a vital role in the biosphere and have regional ecological and environmental functions, such as flood mitigation, food production, water purification, and wildlife habitat [2-4]. However, despite their immeasurable value, floodplain wetlands are considerably disturbed and endangered by human activities, which include land reclamation, dam construction, and other regulatory measures [5-7]. Dam construction, which is often cited as the most significant source of anthropogenic disturbance on wetland around the world, is convenient for water storage, navigation, and hydropower [6,8,9]. It is reported that nearly half of the world's wetlands have been disturbed by large dams, which has lead to numerous hydro-ecological and environmental problems $[10,11]$.

Wetland-aquatic ecosystems have multiple and complex responses to dams. These responses occur as a result of several sequential and associated processes (Figure 1). First, the operation of dams results in immediate and obvious changes in the inundation regime [12]. Dam operation can directly alter the wetland inundation magnitude, duration, frequency, and rate by modifying the seasonality of 
water flows [6]. Second, as the growth and regeneration of wetland vegetation is strongly dependent on, as well as related and adapted to hydrological regimes $[13,14]$, changes in inundation patterns can lead to alterations in the structure, distribution, and function of floodplain vegetation [15,16]. Lastly, these changes in the inundation regime and floodplain vegetation could profoundly alter the structure and composition of the wetland land cover, resulting in alterations of regional landscape and environmental effects $[17,18]$. Therefore, understanding how the above-mentioned hydro-ecological characteristics respond to dams is one of the key issues for the management and conservation of the floodplain wetlands $[19,20]$.

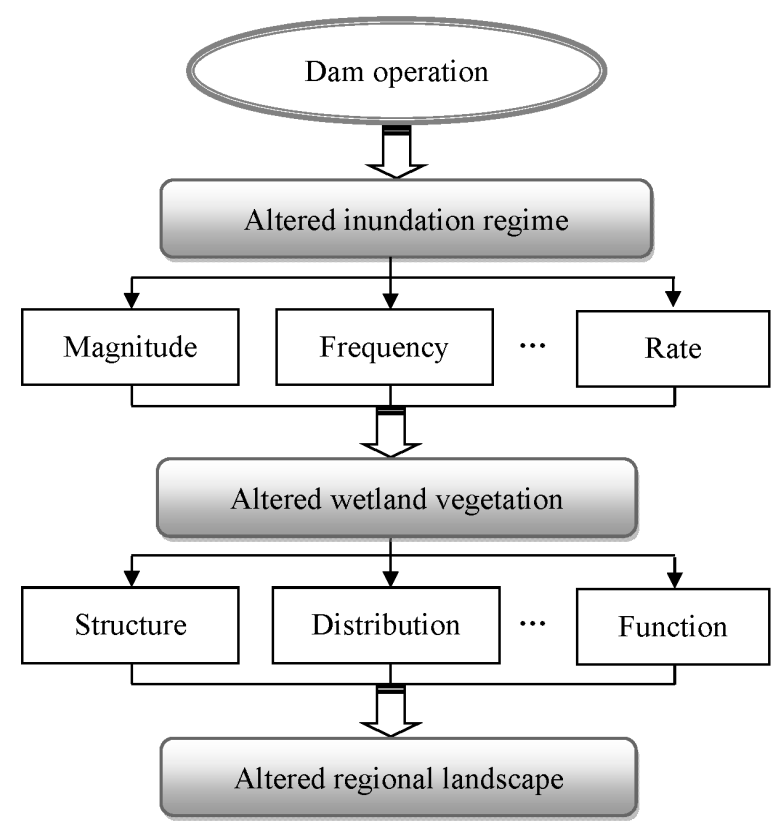

Figure 1. A flow chart of a wetland's hydro-ecological processes that respond to dam operation.

Poyang Lake, a famous international wetland, is the largest freshwater lake in China. It is recognized as an important wetland of extraordinary biological diversity with abundant and diverse populations of migratory birds, invertebrate species, and aquatic plants [21,22]. Poyang Lake has complex flow regimes because of its interaction with the Yangtze River [23]. Notably, it has been reported that Poyang Lake has been undergoing hydrological and ecological alterations in recent decades since the operation of the Three Gorges Dam (TGD) [24-26], the world's largest hydropower project in the middle reach of the Yangtze River (see Figure 2). At present, numerous studies have been performed to explore the potential linkages between the abrupt changes in the Poyang Lake wetland and the operation of the TGD [27-30]. However, most studies have focused on the assessment of the impact on single factors, such as flow regime [31,32], waterbirds [33], and vegetation [29]. No study has been conducted on the dam-induced hydro-ecological impact on Poyang Lake from a systemic and spatial-quantitative perspective. What specific hydrological, vegetation, and landscape changes have occurred in Poyang Lake after the operation of the TGD? How will changes in the hydrological regime alter plant distribution and landscape characteristics? Much of our knowledge on the extent, process, and magnitude of the TGD-induced effects remains unclear, making it difficult to conduct a comprehensive assessment of the eco-environmental changes in the Poyang Lake wetland.

Therefore, the present study aims to provide a comprehensive assessment of the hydro-ecological impacts on Poyang Lake following the operation of the TGD by using remote sensing and GIS analysis techniques. This goal will be addressed through the following primary objectives: (1) to systemically assess the extent and magnitude of the influence that the TGD construction has imposed on the local inundation pattern, vegetation distribution, and landscape characteristics; (2) to reveal the relationships between hydrological and eco-environmental changes in Poyang Lake during the post-TGD period; 
and (3) to provide insights into an ecosystem impact assessment for the TGD that may be useful elsewhere in the world. Our findings should be valuable for hydrology-related administrations to provide policies and restoration strategies aimed at maintaining the ecological services of the Poyang Lake wetland.

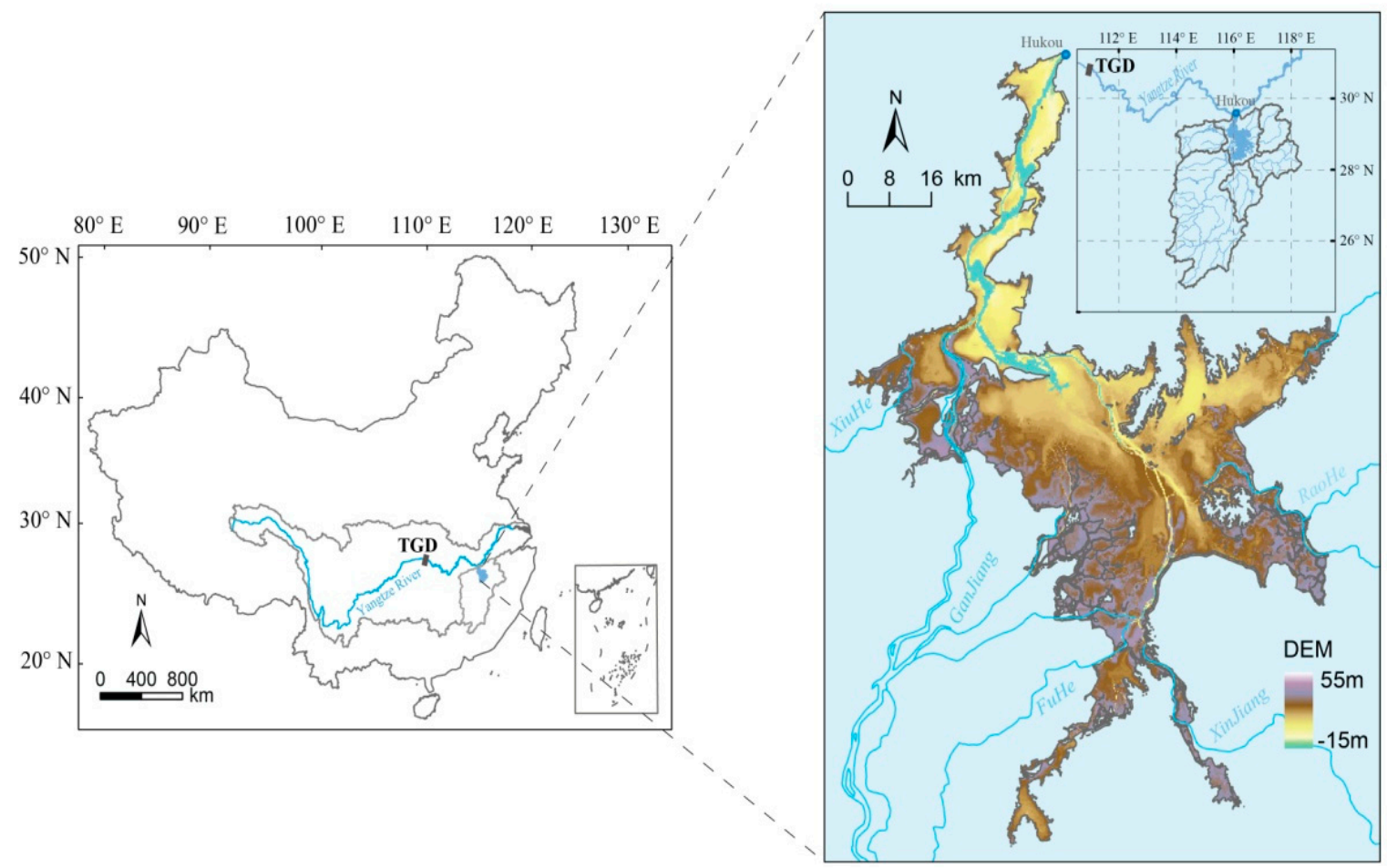

Figure 2. Geographical location of the Poyang Lake wetland and the Three Gorges Dam (TGD) in China.

\section{Study Area and Data Used}

\subsection{Study Area}

Poyang Lake $\left(28^{\circ} 22^{\prime}-29^{\circ} 45^{\prime} \mathrm{N}, 115^{\circ} 47^{\prime}-116^{\circ} 45^{\prime} \mathrm{E}\right)$, located in the middle reach of the Yangtze River, is the largest freshwater lake in China. It is well known and was specified in the first batch of the Ramsar Convention list in 1992 [21]. As shown in Figure 2, Poyang Lake receives water that flows primarily from five rivers-XiuHe, GanJiang, FuHe, XinJiang and RaoHe-and discharges into the Yangtze River. The five tributaries divide at their mouth and form estuary delta zones in the southwestern region of the lake. In addition to the five main tributaries that drain into the lake, Poyang Lake also receives seasonal, reverse-flow from the Yangtze River, which greatly contributes to the complexity of the water level variation [34]. During high-water seasons (April-September), the five tributaries are substantially more swollen due to heavy rainfall. Water levels in the lake reach a peak with the blocking effect of the Yangtze River, and the lake area can exceed $3000 \mathrm{~km}^{2}$ [35]. During low-water seasons (October-March), the lake recedes into shallow depressions and channels. At this time, the lake can lose as much as $90 \%$ of its water, and the size of the lake declines to less than $1000 \mathrm{~km}^{2}$ [36,37].

The TGD, one of the largest dams in the world, is located in the upper-middle mainstream of the Yangtze River, approximately $1050 \mathrm{~km}$ upstream of Poyang Lake (Figure 2). It is an annual storage reservoir that is mainly used for flood control, power generation, and shipping. The construction of the TGD was launched in 1993, and the dam began storing water to $139 \mathrm{~m}$ in 2003 [38,39]. It has a total storage capacity of 39.3 billion $\mathrm{m}^{3}$, approximately $4.5 \%$ of the Yangtze River's annual discharge. The dispatch modes for the TGD are as follows: (1) pre-discharge dispatch, water release in late May-early June to empty the flood control capacity; (2) flood-control dispatch, flow regulation 
in July-August; (3) water-storage dispatch, water impounding in mid-September-October for electricity generation and water supply in winter; and (4) water-supplement dispatch, water release in December-April [40]. This normal operation of the TGD may result in significant changes in the flow regime of Poyang Lake.

\subsection{Data Acquisition and Pre-Processing}

Moderate resolution imaging spectroradiometer (MODIS) satellite data (MOD02_QKM and MOD02_HKM) from February 2000 to December 2014 (a total of 718 cloud-free images near the satellite scan center) were acquired from the NASA Goddard Space Flight Center (GSFC) (http:/ /ladsweb.nascom.nasa.gov), and used to delineate the lake's inundation extent. There was at least one scene for each month. The MOD02_QKM and MOD02_HKM datasets contain Level-1B calibrated and geo-located radiances for the visible and near infrared (NIR) bands. MOD02_HKM was extracted for the DN (digital number) values in the green band $(0.54-0.57 \mu \mathrm{m})$ at a $500 \mathrm{~m}$ resolution, and MOD02_QKM was extracted for the DN values in the NIR band $(0.84-0.88 \mu \mathrm{m})$ at a $250 \mathrm{~m}$ resolution. The MODIS green band was resampled to a $250 \mathrm{~m}$ resolution to match the resolution of the MODIS NIR band. Additionally, long-term Landsat instrument (i.e., MSS, TM, ETM+ and OLI) images of Poyang Lake during both the pre- and post-TGD period were used in this study to investigate the wetland vegetation and landscape changes under different hydrological conditions. Landsat series data were acquired from the Global Land Cover Facility (GLCF) (http://glcf.umd.edu/data/landsat/) and have a fine spatial resolution of $30 \mathrm{~m}$. All of the acquired remote sensing images can be seen in Table 1. They were registered to the Universal Transverse Mercator (UTM) with a World Geodetic System (WGS-84) datum, and had an RMS error of less than 0.5 pixels.

Besides these multi-temporal remote sensing data, daily runoff data (during 1978-2014) from five gauging stations (Wanjiabu, Waizhou, Lijiadu, Meigang, and Shizhenjie) in the five main tributaries (Figure 2) were obtained from the Hydrological Bureau of the Yangtze River Water Resources Commission of China. These data were summed to represent the total runoff of Poyang Lake, which will aid in selecting the typical hydrological year in the pre-TGD (1980-2003) and post-TGD (2004-2014) periods.

Table 1. Terra moderate resolution imaging spectroradiometer (MODIS) and Landsat instruments images used in this study.

\begin{tabular}{cccccc}
\hline \multicolumn{2}{c}{ Satellite Imagery } & Spatial Resolution (m) & Spectral Resolution $(\mu \mathrm{m})$ & Band & Temporal Coverage \\
\hline \multirow{2}{*}{ EOS-Terra } & MOD02_HKM & 500 & Green: $0.54-0.57$ & 4 & \multirow{2}{*}{$2000-2015$} \\
& MOD02_QKM & 250 & NIR: $0.84-0.88$ & 2 & \multirow{2}{*}{ Landsat } \\
& \multirow{2}{*}{ TM/ETM+/OLI } & \multirow{2}{*}{30} & Green: $0.52-0.60$ & 2 & NIR: $0.76-0.90$ \\
\hline
\end{tabular}

\section{Methods}

(1) Determination of a representative year for pre- and post-dam periods:

Based on analysis of gauging station data, the representative hydrological year is defined as a year that presented values closest to average for the historical series analyzed [41]. In this study, we selected the representative hydrological year by computing the annual runoff data from pre- and post-TGD periods, which corresponded more clearly to the average annual runoff during each period. We first divided the gauging station data series into pre- and post-dam periods based on the time of dam completion. Then, by comparing the total annual runoff with the average annual runoff during the preand post-dam periods, we determined a representative year for the pre- and post-dam periods. A year is considered as a representative year if the total annual amount of runoff has a good approximation to the average annual runoff of the corresponding periods. Using this approach, the long-term hydrological condition characteristics and dynamic system's behavior can be evaluated [40]. This approach has 
been used in previous hydrological and meteorological studies [40,42,43], and has been proven for its reliability and validity for selecting the representative year [44,45].

(2) Water surface delineation and variation:

Water surface is one of the most discernible targets in remote sensing due to its special spectral characteristics [46]. In this study, the normalized difference water index (NDWI) [47] method was used to extract the water surface. The NDWI, which is defined as the difference between the reflectance observed in the green band and the near infrared (NIR) band divided by the sum of the two reflectance values, can differentiate water surfaces from most terrestrial features [48]. The MODIS DN values were first transformed into NDWI values. Then, an optimal threshold value was determined to separate the water surface from its background based on the histogram distribution of NDWI [49].

To depict the spatial patterns of water inundation in the pre- and post-dam periods, inundation frequency (IF) methodology was used. IF describes the probability of water submergence, which was calculated as the number of times a grid cell is inundated divided by the total number of times a grid cell is imaged in each grid cell. The method is detailed in Wu et al. (2014) [50]. Briefly, the IF is defined as follows:

$$
P(m)=\frac{1}{N_{m}} \sum_{t=1}^{N_{m}} w_{m, t} \times 100 \%
$$

where $P(m)$ is the monthly inundation frequency, $m$ is the month of the year, $N_{m}$ is the number of days inundated in month $m$, and $w_{m, t}$ denotes whether a pixel is inundated.

\section{(3) Derivation of landscape information:}

The classification system and class definitions of Han et al. [51] were used in this study. The land-cover categories of the study area were divided into four major types, including vegetation, mudflat, sand, and water. A supervised classification method, maximum likelihood classification [52], was used to classify the Landsat series images. To ensure high classification accuracy, the detailed land cover maps were validated based on a combination of ground surveys and high-resolution imagery. The overall accuracy for each classified image was estimated to be no less than $85 \%$.

Landscape metrics are one of the most popular methods for the quantification of landscape patterns [53]. Numerous landscape metrics have been developed to quantify landscape structures. However, many of these are correlated and exhibit statistical interactions with each other [54]. In this study, in order to quantify landscape pattern and analyze landscape dynamics, six landscape metrics indicating landscape fragmentation, shape, and diversity information at the landscape level were calculated using FRAGSTATS 4.2 based on $30 \mathrm{~m}$ resolution land cover maps. The number of patches (NP) and mean patch area (AREA_MN) were used to quantify the fragmentation information. Edge density (ED) and the Mean Fractal Dimension Index (FRAC_MN) were used to measure the shape and size information. The Contagion (CONTAG) and Shannon's diversity index (SHDI) were used to quantify the compositional and structural components of the diversity information. For more detailed mathematical expressions and the ecological meanings of these metrics, please refer to the FRAGSTATS software manual [53].

\section{Results}

\subsection{Representative Pre- and Post-TGD Year}

For the present study, the timing of the TGD impoundment (in 2003) was used as a changing point to divide the pre-impact (1980-2003) and post-impact (2004-2014) periods. As shown in Table 2, during the pre-TGD period, the annual runoff in 1989 was $1260.40 \times 10^{8} \mathrm{~m}^{3}$, with a good approximation to the average annual runoff of $1260.85 \times 10^{8} \mathrm{~m}^{3}$. In 2013, $1135.37 \times 10^{8} \mathrm{~m}^{3}$ of total annual runoff was received, and the difference was minimal compared with the average annual runoff of the post-TGD 
period. Therefore, 1989 was considered as a representative year for the pre-TGD period, whereas 2013 was characterized as a representative year for the post-TGD period.

Table 2. The comparisons of total annual runoff with average annual runoff for the pre-Three Gorges Dam (TGD) and post-TGD periods.

\begin{tabular}{|c|c|c|c|c|c|}
\hline Pre-TGD & $\begin{array}{l}\text { Inflow Discharge from } \\
\text { Five Rivers }\left(10^{8} \mathrm{~m}^{3}\right)\end{array}$ & $\begin{array}{l}\text { Difference } \\
\left(10^{8} \mathrm{~m}^{3}\right)\end{array}$ & Post-TGD & $\begin{array}{c}\text { Inflow Discharge } \\
\text { from Five Rivers }\left(10^{8} \mathrm{~m}^{3}\right)\end{array}$ & $\begin{array}{l}\text { Difference } \\
\left(10^{8} \mathrm{~m}^{3}\right)\end{array}$ \\
\hline 1978 & 816.53 & -444.32 & 2004 & 732.73 & -402.75 \\
\hline 1979 & 785.73 & -475.12 & 2005 & 1178.53 & 43.05 \\
\hline 1980 & 1254.52 & -6.33 & 2006 & 1306.91 & 171.43 \\
\hline 1981 & 1240.04 & -20.81 & 2007 & 814.64 & -320.84 \\
\hline 1982 & 1250.02 & -10.83 & 2008 & 1015.69 & -119.79 \\
\hline 1983 & 1630 & 369.15 & 2009 & 833.30 & -302.18 \\
\hline 1984 & 1168.8 & -92.05 & 2010 & 1766.45 & 630.97 \\
\hline 1985 & 1012.95 & -247.9 & 2011 & 730.15 & -405.33 \\
\hline 1986 & 804.57 & -456.28 & 2012 & 1742.91 & 607.43 \\
\hline 1987 & 995.10 & -265.75 & 2013 & 1135.37 & -0.11 \\
\hline 1988 & 1220.22 & -40.63 & 2014 & 1248.50 & 113.02 \\
\hline 1989 & 1260.40 & -0.45 & - & - & - \\
\hline 1990 & 1108.63 & -152.22 & - & - & - \\
\hline 1991 & 1012.6 & -248.25 & - & - & - \\
\hline 1992 & 1551.34 & 290.49 & - & - & - \\
\hline 1993 & 1341.91 & 81.06 & - & - & - \\
\hline 1994 & 1494.41 & 233.56 & - & - & - \\
\hline 1995 & 1646.75 & 385.9 & - & - & - \\
\hline 1996 & 1071.94 & -188.91 & - & - & - \\
\hline 1997 & 1532.99 & 272.14 & - & - & - \\
\hline 1998 & 2076.13 & 815.28 & - & - & - \\
\hline 1999 & 1464.89 & 204.04 & - & - & - \\
\hline 2000 & 1122.62 & -138.23 & - & - & - \\
\hline 2001 & 1210.68 & -50.17 & - & - & - \\
\hline 2002 & 1615.39 & 354.54 & - & - & - \\
\hline 2003 & 1087.97 & -172.88 & - & - & - \\
\hline average & 1260.85 & 0 & average & 1135.48 & 0 \\
\hline
\end{tabular}

\subsection{TGD-Triggered Inundation Pattern Variation}

A comparison of estimated monthly mean IF maps during the pre- and post-TGD periods is illustrated in Figure 3, where the left column and right columns denote the IFs of the pre- and post-TGD periods, respectively. As shown in Figure 3, in both periods, there was a strong seasonality in the IFs from January to December because of seasonal variations in the precipitation and water exchange with the Yangtze River. Likewise, TGD regulation obviously changed the spatial and temporal patterns of the inundation extent and frequency. Before the operation of the TGD, the monthly mean IF increased slowly from north to south during January-August, and decreased rapidly from south to north during September-December. However, after the TGD was placed into operation, the flow of the Yangtze River was altered, which changed the inundation duration of the bottomland of Poyang Lake. Compared with the pre-TGD monthly IFs, in general, the IFs in each month were reduced after the TGD regulation, which is especially notable from September to November. This coincides with the period when the TGD impounds water for electricity generation in winter (Figure 3). Therefore, these observed reductions in IFs should be due to the lower discharge caused by the water storage of the TGD reservoir. In addition, all of the bed load transported from the upper reaches would have been trapped after the operation of the TGD. The cleaner outflow would then cause long-distance scour below the dam. The river cross-sectional areas increased due to scour, and this in turn also lowered the IFs in relation to the discharges. Specifically, the TGD regulation decreased the IFs by between 30-40\% in the northern lake body zone from September to November. These reduced IFs account for a large 
proportion of the water volume of Poyang Lake, and cause the low exposure rates of the bottomland to occur earlier and last longer.

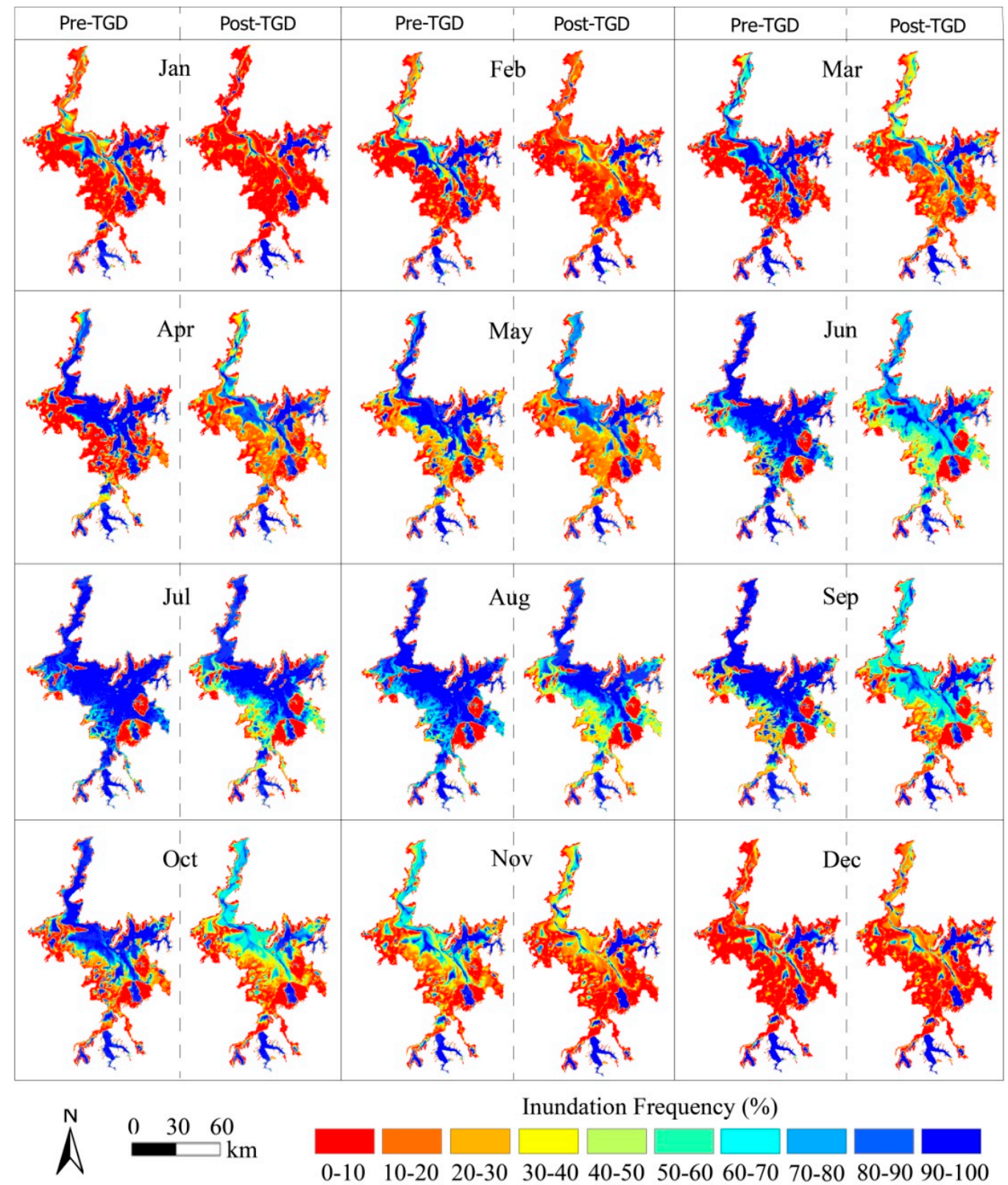

Figure 3. Poyang Lake's monthly mean inundation frequency (IF) during the pre- and post-TGD periods derived from remote sensing (left column: pre-TGD; right column: post-TGD).

\subsection{Assessment of TGD Effects on Land-Cover Change and Vegetation Distribution}

Based on the availability of the acquired remote sensing data, Landsat series images from 13/02/1989 (low-water season), 15/07/1989 (high-water season), 24/12/2013 (low-water season), and 01/07/2013 (high-water season) were selected to represent the pre- and post-TGD periods, respectively. Based on knowledge of cover types, we constructed training data sets. The study area was classified into four land cover types, i.e., sand, mudflat, water, and vegetation, using supervised classification. To assess the classification accuracy, ground survey data and high resolution historical images from Google Earth ${ }^{\mathrm{TM}}$ (http:/ / earth.google.com/) were used as the ground truth data [51]. The classification accuracy for each scene was evaluated using a stratified random sampling design, 
which selected a minimum of 400 pixels for each category for checking. The classification results shown in Table 3 indicate high overall accuracies for each date, with Kappa indices ranging from 0.863 to 0.911 . Then, by evaluating land cover distribution maps in the two representative years, the spatio-temporal variation of land-cover patterns in the Poyang Lake wetland were analyzed, and are shown in Figure 4. The results show that natural vegetation and the water body are the dominant land cover categories in Poyang Lake. Likewise, different land cover types show different patterns of change with respect to the area between the two study periods and among the subdivided sections and zones. A remarkable reduction in the water area of Poyang Lake is mainly observed from the pre- to the post-TGD period. The water area decreased from $1455.81 \mathrm{~km}^{2}$ to $1135.89 \mathrm{~km}^{2}$ in the low-water season, and from $3450.57 \mathrm{~km}^{2}$ to $2752.91 \mathrm{~km}^{2}$ in the high-water season. In addition, the declining water area resulted in an intensive increase in the marshland area, which is suitable for the growth of vegetation. Generally, the regeneration of wetland vegetation can be hindered if the inundation frequency remains too high [37]. The higher inundation frequency could lead to the extermination of wetland vegetation through the reduction of light or atmospheric gas availability. However, the increased marshland area with moderate inundation frequency is likely to greatly facilitate the fitness of adult plants, which is beneficial for seed regeneration. Likewise, according to Figure 3, from the pre- to the post-TGD period, there is a larger decrease in inundation frequency during the high-water season than during the low-water season. For this reason, the vegetation area increased by $58.82 \mathrm{~km}^{2}$ in the low-water season and $463.73 \mathrm{~km}^{2}$ in the high-water season, with the most significant changes occurring in the estuary delta of the Ganjiang and Raohe Rivers.

Table 3. Accuracy assessment of the land-cover classification results.

\begin{tabular}{cccc}
\hline Date & Image Source & Overall Accuracy & Kappa \\
\hline $1989 / 2 / 13$ & Landst-5 TM & $86.78 \%$ & 0.863 \\
$1989 / 7 / 15$ & Landst-5 TM & $88.82 \%$ & 0.887 \\
$2013 / 12 / 24$ & Landst-8 OLI & $92.01 \%$ & 0.904 \\
$2013 / 7 / 1$ & Landst-8 OLI & $93.34 \%$ & 0.911 \\
\hline
\end{tabular}

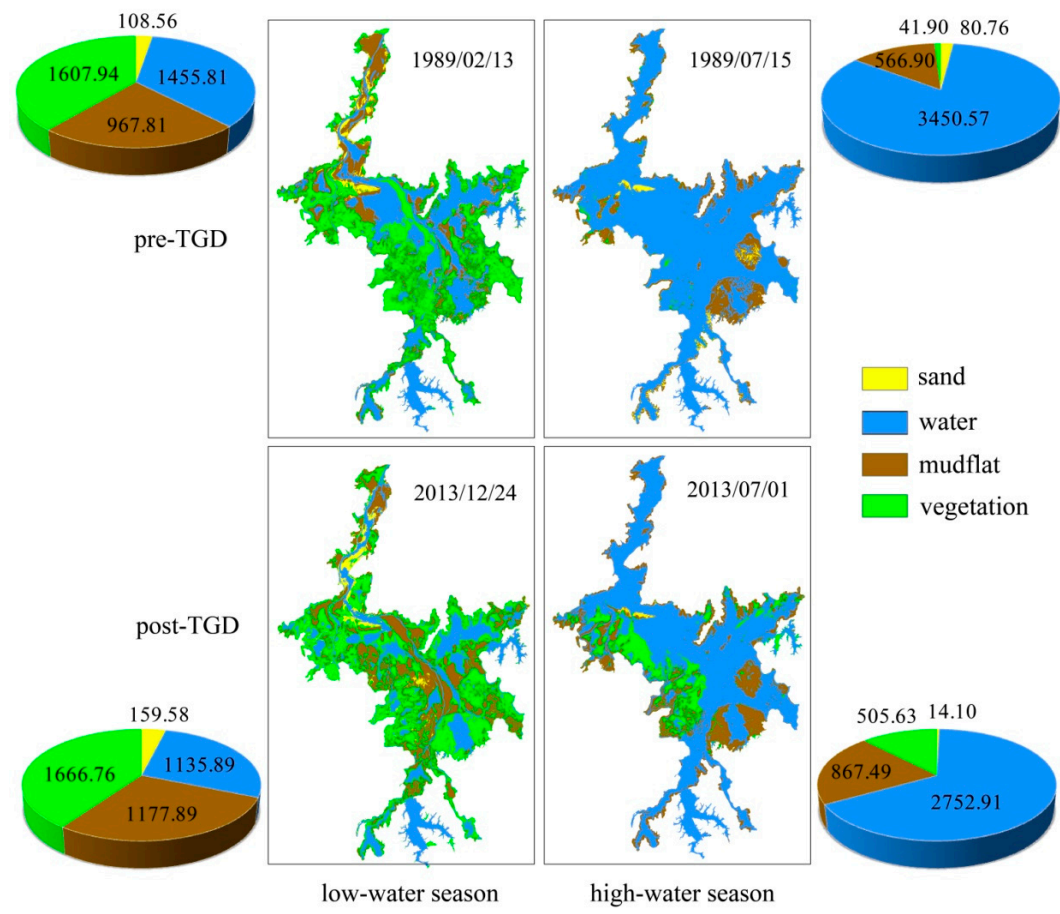

Figure 4. Land cover/land use maps during different periods produced by image classification. 
Poyang Lake is an important natural wetland for the flow of energy and materials and the maintenance of biodiversity. The floodplain area is extremely sensitive to hydrologic regime changes. It was found that the operation of the TGD is the dominant human driver that has impacted the regional vegetation distribution pattern. As a result, the duration of beach submergence, water inundation, and sediment deposition changes associated with regulation of the TGD might be the most important eco-hydrological factors altering the floodplain vegetation structure and distribution in Poyang Lake. Likewise, the impact of the TGD on floodplain vegetation was inundation from the decreased water IFs after TGD operation. The partially inundated area was replaced by marshland, and, accompanying this process, the floodplain plants grew and expanded. In addition, over a long-term scale, decreasing water IFs in Poyang Lake after TGD operation may affect plant regeneration and vegetation succession. This will lead to changes, including perhaps even a loss of biodiversity, and the possible degradation of wetland services.

\subsection{Landscape Changes from the Pre- to Post-TGD Period}

Based on land-cover classification results, we converted the classification data to raster format and imported them into the FRAGSTATS software program to calculate the landscape metrics. Table 4 shows the changes in the landscape metrics from the pre- to the post-TGD period. During the pre-TGD period, the landscape was composed of 27,659 and 14,942 patches in the low- and high-water season, respectively. However, during the post-TGD period, there was a significant increase in NPs (to 32,144 and 18,741, respectively), a decrease in the AREA_MN (from 12.8319 to 10.968 and from 27.7181 to 22.09 , respectively), and there were higher ED and FRAC_MN values. These results indicate that the increase in landscape fragmentation and the regional landscape tends to become more complex and heterogeneous. On the other hand, the CONTAG value decreased from 46.5759 to 42.1618 in the low-water season, and decreased from 75.8117 to 62.2445 in the high-water season, indicating that the connectivity among the dominant patches declined, and the patches were distributed more unevenly after the TGD construction. In addition, after the TGD construction, SHDI increased from 1.0705 to 1.3043 , and from 0.5472 to 0.875 , during the low- and high-water seasons, respectively.

Table 4. Landscape metric evolution for the entire landscape (landscape level) from the pre- to the post-TGD period.

\begin{tabular}{clcccccc}
\hline Metrics & $\begin{array}{c}\text { Number of } \\
\text { Patches (NP) }\end{array}$ & $\begin{array}{c}\text { Mean Patch } \\
\text { Area } \\
\text { (AREA_MN) }\end{array}$ & $\begin{array}{c}\text { Edge } \\
\text { Density } \\
\text { (ED) }\end{array}$ & $\begin{array}{c}\text { Mean Fractal } \\
\text { Dimension } \\
\text { (FRAC_MN) }\end{array}$ & $\begin{array}{c}\text { Contagion } \\
\text { Index } \\
\text { (CONTAG) }\end{array}$ & $\begin{array}{c}\text { Shannon's } \\
\text { Diversity } \\
\text { Index (SHDI) }\end{array}$ \\
\hline \multirow{2}{*}{ pre-TGD } & low-water & 27,659 & 12.8319 & 47.1901 & 1.0126 & 46.5759 & 1.0705 \\
& high-water & 14,942 & 27.7181 & 17.6297 & 1.0331 & 75.8117 & 0.5472 \\
\hline \multirow{2}{*}{ post-TGD } & low-water & 32,144 & 10.968 & 50.7056 & 1.0524 & 42.1618 & 1.3043 \\
& high-water & 18,741 & 22.09 & 23.869 & 1.0666 & 62.2445 & 0.875 \\
\hline
\end{tabular}

The landscape pattern is linked to biodiversity and other ecological processes of wetlands (Ouyang et al., 2010). Human-induced land use change could cause intense impacts on regional landscape composition and structure, which also have significant impacts on local environmental quality and species diversity. The landscape metric results demonstrate that the landscape diversity increased, and the composition of the ecosystem gradually became more complex and fragmented under the influence of the TGD regulation. These changes will alter regional connectivity, and in turn, will modify hydrologic regime sediment movement, resulting in other effects on the habitat and aquatic organisms. As a result, in Poyang Lake, the landscape changes influenced by the TGD may threaten biodiversity, habitats, and the survival of migratory birds. Consequently, this result points to a strong need for working strategies to balance the TGD impacts on ecological services in Poyang Lake. 


\section{Discussion}

The multiple responses of wetland ecosystems to dams are generally well known, which occur as a result of several sequential processes, including the changes in inundation regime, wetland vegetation, and regional landscape. Comprehensively understanding how these hydro-ecological processes respond to dams is critical for the management and conservation of the floodplain wetlands. The primary objective of this study is to provide an extensive assessment of the hydro-ecological impacts on Poyang Lake wetland associated with the TGD construction. To summarize, compared with existing studies, the contributions of this study to the literature are mainly on three aspects. On the one hand, previous studies have only focused on the assessment of the TGD impacts that consider the effects on flow regime [31,32], waterbirds [33], or vegetation [29]. No study has been conducted on the TGD-induced hydro-ecological impact on Poyang Lake from a systemic and spatial-quantitative perspective. However, the assessment of dam impacts requires a holistic analysis that considers all possible factors. To address this gap, this study constructed a framework and made a comprehensive assessment to show how dam operation affects each hydro-ecological process of floodplain wetlands. To the best of our knowledge, this is the first attempt to systematically investigate the hydro-ecological alteration (including inundation regime, vegetation distribution, and landscape characteristics) of the Poyang Lake wetland associated with the TGD operation. On the other hand, from a methodological point of view, this study describes how the integration of remote sensing data, along with GIS analysis techniques, can conduct research on dam-induced hydro-ecological responses. More importantly, unlike previous studies, this study focuses on the GIS-based spatial-quantitative analysis of the dam's effects by using different indices, including inundation frequency and landscape metrics, rather than only relying on temporal comparisons [26,31,32]. We believe that the program and approach demonstrated here may provide a reference for similar wetlands in the world to evaluate hydro-ecological alterations, and expect to continue this type of assessment in order to help inform policy and decisions to mitigate the potential environmental impacts once the lake's dam is established. Finally, the results presented here also have significant implications for other hydro-ecological research on Poyang Lake, as well as wetland environmental management. For example, the Poyang Lake Dam has been designed as a $2.8 \mathrm{~km}$ wide dam with sluice gates across the narrowest part of the channel, which links Poyang Lake and the Yangtze River [55]. The findings of this study can provide practical guidance in the construction of the proposed dam, and can facilitate the development of corresponding hydro-ecological strategies. In addition, the derived inundation frequency maps, land cover/land use products and revealed landscape dynamics also provide a fundamental and necessary monitoring basis for the continuous investigation of migratory birds and invertebrate species in the Poyang Lake system.

\section{Conclusions}

This study provides a comprehensive assessment of the hydro-ecological impacts on Poyang Lake following the TGD operation using remote sensing and GIS analysis techniques. There are several results that are worth pointing out. First, the operation of the TGD alters the seasonal inundation pattern of Poyang Lake, and significantly reduces the monthly IFs. Reductions in variability of up to $30-40 \%$ have been observed in the TGD impoundment months of September to November. Second, the declining IFs result in an intensive increase in marshland area that is suitable for the growth of vegetation. The vegetation area increases by $58.82 \mathrm{~km}^{2}$ and $463.73 \mathrm{~km}^{2}$ in the low- and high-water seasons, respectively, with the most significant changes occurring in the estuary delta of the Ganjiang and Raohe rivers. Third, the changes in the inundation pattern and floodplain vegetation profoundly alter the structure and composition of the wetland land cover in Poyang Lake, resulting in an increase in landscape diversity and the composition of the ecosystem becoming gradually more complex under the influence of the TGD regulation.

The findings here have significant implications for hydrological and ecological research and lake environmental management, which can greatly help improve the understanding of the effects of the 
TGD on the hydro-ecological processes in Poyang Lake, and can be applied to other large wetlands around the world. Likewise, there are two additional issues that require further attention. For one thing, this study merely presents an overview of the changes that have occurred in the inundation pattern, vegetation distribution, and landscape structure of Poyang Lake after the TGD operation. Further research on the specific influencing mechanisms is required, which can be conducted through long-term hydro-ecological surveys in the vicinity of the lake beaches. There is also a serious challenge associated with the TGD with respect to balancing the conflicts between the protection of wetland ecosystems and human needs. To mitigate the hydrological alteration and minimize the negative hydro-ecological impacts, it is essential to optimize the existing operational rules or develop new management strategies without significantly affecting the main purposes of the TGD.

Acknowledgments: This work was supported by the State Key Program of National Natural Science of China (41430855), National Natural Science Foundation of China (41401506).

Author Contributions: Guiping Wu carried out data processing, data analysis and wrote the paper. Yuanbo Liu offered guidance to complete the work.

Conflicts of Interest: The authors declare no conflicts of interest.

\section{References}

1. Arias, M.E.; Cochrane, T.A.; Kummu, M.; Lauri, H.; Holtgrieve, G.W.; Koponen, J.; Piman, T. Impacts of hydropower and climate change on drivers of ecological productivity of Southeast Asia's most important wetland. Ecol. Model. 2014, 272, 252-263. [CrossRef]

2. Constanza, R.; d'Arge, R.; De Groot, R.; Faber, S.; Grasso, M.; Hannon, B.; Raskin, R.G. The value of the world's ecosystem services and natural capital. Nature 1997, 387, 253-260. [CrossRef]

3. Johnson, N.; Revenga, C.; Echeverria, J. Managing water for people and nature. Science 2001, 292, 1071-1072. [CrossRef] [PubMed]

4. Millennium, E.A. Ecosystems and Human Well-Being: Wetlands and Water Synthesis; World Resources Institute: Washington, DC, USA, 2005.

5. Nilsson, C.; Reidy, C.A.; Dynesius, M.; Revenga, C. Fragmentation and flow regulation of the world's large river systems. Science 2005, 308, 405-408. [CrossRef] [PubMed]

6. Poff, N.L.; Olden, J.D.; Merritt, D.M.; Pepin, D.M. Homogenization of regional river dynamics by dams and global biodiversity implications. Proc. Natl. Acad. Sci. USA 2007, 104, 5732-5737. [CrossRef] [PubMed]

7. Egger, G.; Politti, E.; Woo, H.; Cho, K.H.; Park, M.; Cho, H.; Lee, H. Dynamic vegetation model as a tool for ecological impact assessments of dam operation. J. Hydro-Environ. Res. 2012, 6, 151-161. [CrossRef]

8. Vorosmarty, C.J.; Sharma, K.P.; Fekete, B.M.; Copeland, A.H.; Holden, J.H.; Marble, J.; Lough, J.A. The storage and ageing of continental runoff in large reservoir systems of the world. Ambio 1997, 26, 210-219.

9. Tiemann, J.S.; Gillette, D.P.; Wildhaber, M.L.; Edds, D.R. Effects of low head dams on riffle-dwelling fishes and macroinvertebrates in a midwestern river. Trans. Am. Fish. Soc. 2004, 133, 705-717. [CrossRef]

10. Maltby, E.; Acreman, M.C. Ecosystem services of wetlands: Pathfinder for a new paradigm. Hydrol. Sci. J. 2011, 56, 1341-1359. [CrossRef]

11. Junk, W.J.; An, S.; Finlayson, C.; Finlayson, C.M.; Gopal, B.; Květ, J.; Mitchell, S.A.; Robarts, R.D. Current state of knowledge regarding the world's wetlands and their future under global climate change: A synthesis. Aquat. Sci. 2013, 75, 151-167. [CrossRef]

12. Lai, X.J.; Jiang, J.H.; Huang, Q. Effects of the normal operation of the Three Gorges Reservoir on wetland inundation in Dongting Lake, China: A modelling study. Hydrol. Sci. J. 2013, 58, 1467-1477. [CrossRef]

13. Arthington, A.H.; Bunn, S.E.; Poff, N.L.; Naiman, R.J. The challenge of providing environmental flow rules to sustain river ecosystems. Ecol. Appl. 2006, 16, 1311-1318. [CrossRef]

14. Naiman, R.J.; Latterell, J.J.; Pettit, N.E.; Olden, J.D. Flow variability and the biophysical vitality of river systems. C. R. Geosci. 2008, 340, 629-643. [CrossRef]

15. Blanch, S.J.; Walker, K.F.; Ganf, G.G. Water regimes and littoral plants in four weir pools of the River Murray, Australia. Regul. Rivers Res. Manag. 2000, 16, 445-456. [CrossRef]

16. Naiman, R.J.; Decamps, H.; McClain, M.E. Riparia: Ecology, Conservation and Management of Streamside Communities; Elsevier Academic Press: San Diego, CA, USA, 2005. 
17. Poff, N.L.; Har, D.D. How Dams Vary and Why It Matters for the Emerging Science of Dam Removal an ecological classification of dams is needed to characterize how the tremendous variation in the size, operational mode, age, and number of dams in a river basin influences the potential for restoring regulated rivers via dam removal. BioScience 2002, 52, 659-668.

18. Ouyang, W.; Hao, F.H.; Zhao, C.; Lin, C. Vegetation response to 30years hydropower cascade exploitation in upper stream of Yellow River. Commun. Nonlinear Sci. Numer. Simul. 2010, 15, 1928-1941. [CrossRef]

19. Kingsford, R.T. Ecological impacts of dams, water diversions and river management on floodplain wetlands in Australia. Austral Ecol. 2000, 25, 109-127. [CrossRef]

20. Magilligan, F.J.; Nislow, K.H. Changes in hydrologic regime by dams. Geomorphology 2005, 71, 61-78. [CrossRef]

21. Finlayson, M.; Harris, J.; McCartney, M.; Lew, Y.; Zhang, C. Report on Ramsar Visit to Poyang Lake Ramsar Site, PR China 12-17 April 2010; Report prepared on behalf of the Secretariat of the Ramsar Convention; The Ramsar Convention of Wetlands: Gland, Switzerland. Available online: http:/ /archive.ramsar.org/pdf/ Poyang_lake_report_v8.pdf (accessed on 15 January 2011).

22. Dronova, I.; Gong, P.; Clinton, N.E.; Wang, L.; Fu, W.; Qi, S.; Liu, Y. Landscape analysis of wetland plant functional types: The effects of image segmentation scale, vegetation classes and classification methods. Remote Sens. Environ. 2012, 127, 357-369. [CrossRef]

23. Hu, Q.; Feng, S.; Guo, H.; Chen, G.; Jiang, T. Interactions of the Yangtze river flow and hydrologic processes of the Poyang Lake, China. J. Hydrol. 2007, 347, 90-100. [CrossRef]

24. Wines, M. China Admits Problems with Three Gorges Dam; New York Times: New York, NY, USA, $2011 ;$ p. 19.

25. Guo, H.; Hu, Q.; Zhang, Q.; Feng, S. Effects of the three gorges dam on Yangtze river flow and river interaction with Poyang Lake, China: 2003-2008. J. Hydrol. 2012, 416, 19-27. [CrossRef]

26. Dai, Z.; Liu, J.T. Impacts of large dams on downstream fluvial sedimentation: An example of the Three Gorges Dam (TGD) on the Changjiang (Yangtze River). J. Hydrol. 2013, 480, 10-18. [CrossRef]

27. Fu, B.J.; Wu, B.F.; Lü, Y.H.; Xu, Z.H.; Cao, J.H.; Niu, D.; Zhou, Y.M. Three Gorges Project: Efforts and challenges for the environment. Prog. Phys. Geogr. 2010, 6, 1-14. [CrossRef]

28. Mei, X.; Dai, Z.; Gelder, P.; Gao, J. Linking Three Gorges Dam and downstream hydrological regimes along the Yangtze River, China. Earth Space Sci. 2015, 2, 94-106. [CrossRef]

29. Feng, L.; Han, X.X.; Hu, C.M.; Chen, X.L. Four decades of wetland changes of the largest freshwater lake in China: Possible linkage to the Three Gorges Dam? Remote Sens. Environ. 2016, 176, 43-55. [CrossRef]

30. Liu, Y.B.; Wu, G.P.; Guo, R.F.; Wan, R.R. Changing landscapes by damming: The Three Gorges Dam causes downstream lake shrinkage and severe droughts. Landsc. Ecol. 2016, 31, 1883-1890. [CrossRef]

31. Zhang, Q.; Li, L.; Wang, Y.G.; Werner, A.D.; Xin, P.; Jiang, T.; Barry, D.A. Has the Three-Gorges Dam made the Poyang Lake wetlands wetter and drier? Geophys. Res. Lett. 2012, 39. [CrossRef]

32. Gao, B.; Yang, D.; Yang, H. Impact of the Three Gorges Dam on flow regime in the middle and lower Yangtze River. Quat. Int. 2013, 304, 43-50. [CrossRef]

33. Wang, Y.; Jia, Y.; Guan, L.; Lu, C.; Lei, G.; Wen, L.; Liu, G. Optimising hydrological conditions to sustain wintering waterbird populations in Poyang Lake National Natural Reserve: Implications for dam operations. Freshw. Biol. 2013, 58, 2366-2379. [CrossRef]

34. Hui, F.; Xu, B.; Huang, H.; Yu, Q.; Gong, P. Modelling spatial-temporal change of Poyang Lake using multitemporal Landsat imagery. Int. J. Remote Sens. 2008, 29, 5767-5784. [CrossRef]

35. Shankman, D.; Keim, B.D.; Song, J. Flood frequency in China's Poyang Lake region: Trends and teleconnections. Int. J. Climatol. 2006, 26, 1255-1266. [CrossRef]

36. Feng, L.; Hu, C.M.; Chen, X.L.; Cai, X.B.; Tian, L.Q.; Gan, W.X. Assessment of inundation changes of Poyang Lake using MODIS observations between 2000 and 2010. Remote Sens. Environ. 2012, 121, 80-92. [CrossRef]

37. Wu, G.; Liu, Y. Capturing variations in inundation with satellite remote sensing in a morphologically complex, large lake. J. Hydrol. 2015, 523, 14-23. [CrossRef]

38. Stone, R. The Legacy of the Three Gorges Dam. Science 2011, 333, 817. [CrossRef] [PubMed]

39. Xu, X.; Tan, Y.; Yang, G. Environmental impact assessments of the Three Gorges Project in China: Issues and interventions. Earth-Sci. Rev. 2013, 124, 115-125. [CrossRef]

40. Ou, C.; Li, J.; Zhang, Z.; Li, X.; Yu, G.; Liao, X. Effects of the dispatch modes of the three gorges reservoir on the water regimes in the Dongting Lake area in typical years. J. Geogr. Sci. 2012, 22, 594-608. [CrossRef] 
41. Petrakis, M.; Kambezidis, H.D.; Lykoudis, S. Generation of a "typical meteorological year" for Nicosia, Cyprus. Renew. Energy 1998, 3, 381-388. [CrossRef]

42. Klein, S.A.; Beckman, W.A.; Duffie, J.A. A design procedure for solar heating systems. Sol. Energy 1976, 2, 113-127. [CrossRef]

43. Hu, X.Y.; Zhang, X.B.; Huang, Y. Research on change of coming sediment and coming water of middle-lower Yangtze River after TGP early operation. J. Yangtze River Sci. Res. Inst. 2010, 6, 4-9. (In Chinese)

44. Wu, B.; Wang, G.; Liu, C.; Xu, Z. Modeling impacts of highly regulated inflow on thermal regime and water age in a shallow reservoir. J. Hydroinform. 2013, 4, 1312-1325. [CrossRef]

45. Durães, M.F.; Mello, C.R. Groundwater recharge behavior based on surface runoff hydrographs in two basins of the Minas Gerais State. Rev. Ambient. Água 2013, 2, 57-66. [CrossRef]

46. Liu, Y.B.; Song, P.; Peng, J.; Ye, C. A physical explanation of the variation in threshold for delineating terrestrial water surface from multi-temporal images: Effects of radiometric correction. Int. J. Remote Sens. 2012, 33, 5862-5875. [CrossRef]

47. McFeeters, S.K. The use of the normalized difference water index (NDWI) in the delineation of open water features. Int. J. Remote Sens. 1996, 17, 1425-1432. [CrossRef]

48. Jain, S.K.; Singh, R.D.; Jain, M.K.; Lohani, A.K. Delineation of flood-prone areas using remote sensing techniques. Water Resour. Manag. 2005, 19, 333-347. [CrossRef]

49. Bryant, R.G. Application of AVHRR to monitoring a climatically sensitive playa. Case study: Chott el Djerid, southern Tunisia. Earth Surface Process. Landf. 1999, 24, 283-302. [CrossRef]

50. Wu, G.P.; Liu, Y.B. Satellite-based detection of water surface variation in China's largest freshwater lake in response to hydro-climatic drought. Int. J. Remote Sens. 2014, 35, 4511-4558. [CrossRef]

51. Han, X.X.; Chen, X.L.; Feng, L. Four decades of winter wetland changes in Poyang Lake based on Landsat observations between 1973 and 2013. Remote Sens. Environ. 2015, 156, 426-437. [CrossRef]

52. Paola, J.D.; Schowengerdt, R.A. A detailed comparison of back propagation neural network and maximum-likelihood classifiers for urban land use classification. IEEE Trans. Geosci. Remote Sens. 1995, 33, 981-996. [CrossRef]

53. McGarigal, K.; Marks, B. Spatial Pattern Analysis Program for Categorical Maps: Computer Software; University of Massachusetts: Amherst, MA, USA, 2002.

54. Gustafson, E.J. Quantifying landscape spatial pattern: What is the state of the art? Ecosystem 1998, 1, $143-156$. [CrossRef]

55. Dam Proposal for Poyang Lake Causes Wave of Controversy. Available online: http:/ /www.chinadaily.com. cn/cndy/2011-08/04/content_13045840.htm (accessed on 8 April 2011). 